\begin{tabular}{l|l|l} 
Jurnal Eksplorasi Akuntansi & $\begin{array}{l}\text { Vol. 2, No 1, Seri B, Februari 2020, Hal 2142-2161 } \\
\text { ISSN : 2656-3649 (Online) } \\
\text { http://jea.ppj.unp.ac.id/index.php/jea/issue/view/18 }\end{array}$
\end{tabular}

\title{
MANAJEMEN ALIRAN KAS DAN DAMPAKNYA TERHADAP NILAI PERUSAHAAN
} (Studi Empiris Pada Perusahaan Manufaktur Yang Terdaftar Di BEI Tahun 2017-2018)

\author{
Dwi Widya Pratiwi ${ }^{1}$, Nurzi Sebrina ${ }^{2}$ Halmawati $^{3}$ \\ ${ }^{1}$ Alumni Jurusan Akuntansi Fakultas Ekonomi Universitas Negeri Padang \\ 2,3 Jurusan Akuntansi Fakultas Ekonomi Universitas Negeri Padang \\ *Korespondensi: dwiwidya1207122@gmail.com
}

\begin{abstract}
Abstrack: This study aims to determine the effect of cash flow management on firm Value. Researchers tested manufacturing companies listed on the Indonesia Stock Exchange in 20172018 with a total sample of 101 samples using a purposive sampling method. In this study, the firm's value is measured using Tobin's $Q$ ratio. Analysis technique used Panel EGLS (Crosssection random effects) analysis. The first model investigates of the three component cash flow measures (days of sales outstanding, days of inventory outstanding and days of payable outstanding), and the last two models investigate the cash conversion cycle and operating cash cycle metrics, respectively. Thechange (A) in one variable for period $t$ is that measured by the differences between at the end of the quarter and at the end of the previous quarter's value. The results showed that days of sales outstanding, days of inventory outstanding, cash conversion cycle and operating cash cycle have a significant effect on firm value.
\end{abstract}

Keywords: Cash Conversion Cycle; Days of Sales Outstanding; Days of Inventory Outstanding; Firm's Value; Operating Cash Cycle.

How to cite (APA $6^{\text {th }}$ style):

Pratiwi, D.W, Sebrina N., Halmawati. (2020). Manajemen Aliran Kas dan Dampaknya Terhadap Nilai Perusahaan (Studi Empiris pada Perusahaan Manufaktur yang Terdaftar di BEI Tahun 2017-2018). Jurnal Eksplorasi Akuntansi. 2(1), Seri B, 2142-2161.

\section{PENDAHULUAN}

Persaingan dalam industri manufaktur pada saat ini membuat setiap perusahaan semakin meningkatkan kinerja agar tujuannya dapat tercapai. Perusahaan mempunyai tujuan jangka panjang dan jangka pendek. Tujuan perusahaan jangka pendek yaitu mendapatkan laba maksimal dengan sumber daya yang ada, sementara dalam jangka panjang tujuan utama perusahaan adalah memaksimalkan nilai perusahaan (Setyanto dan Permatasari, 2014). Menurut Dipanala (2018) nilai perusahaan merupakan salah satu cara untuk melihat apakah perusahaan tersebut sudah berada di posisi baik atau belum. Perusahaan memiliki nilai perusahaan yang baik menunjukkan bahwa posisi para pemegang saham juga sedang dalam kondisi makmur. Nilai perusahaan yang tinggi membuat keinginan investor untuk membeli saham pada perusahaan tersebut juga semakin 
meningkat. Nilai perusahaan (enterprise value atau juga dikenal sebagai firm value) merupakan suatu konsep yang penting bagi investor, karena merupakan indikator bagi investor dipasar saham dalam menilai perusahaan secara keseluruhan.

Pemegang saham mempercayakan pengelolaan kepada pihak manajemen untuk meningkatkan nilai perusahaan, dengan tingginya nilai perusahaan maka keinginan investor untuk membeli saham pada perusahaan tersebut juga semakin meningkat. Nilai perusahaan dapat dilihat melalui kinerja keuangan perusahaan. Kinerja keuangan yang bagus, akan membuat nilai perusahaan semakin meningkat. Kinerja keuangan yang buruk akan menurunkan nilai perusahaan. Kinerja keuangan merupakan salah satu informasi penting yang dilihat oleh investor sebelum memutuskan untuk berinvestasi, karena kinerja keuangan yang baik menggambarkan nilai perusahaan yang baik pula.

Salah satu cara yang dapat digunakan untuk mengukur kinerja keuangan perusahaan yaitu melalui manajemen aliran kas, bagaimana kinerja internal suatu perusahaan dalam mengelola aliran kas sehingga dapat meningkatkan nilai perusahaan tersebut. Investor tertarik dengan aliran kas suatu perusahaan ketika melihat kesempatan untuk berinvestasi dipasar modal karena aliran kas merupakan ukuran kinerja keuangan secara ril (Muraya, 2018), hal ini menunjukkan kas perusahaan yang tersedia setelah mempertimbangkan berapa banyak yang telah dihabiskan untuk pembangunan dan sebagai pengeluaran berulang (Frank dan James, 2014 dalam Ann M. Muraya, 2018).

Pemegang saham bisa menggunakan aliran kas untuk menilai kesehatan keuangan perusahaan. Aliran kas merupakan alat pemeriksa akuntansi akrual yang andal, karena laba yang secara konsisten berbeda dengan arus kas biasanya mencerminkan kualitas yang rendah (Subramanyam, 2010). Manajemen aliran kas menjadi elemen penting bagi strategi operasional perusahaan (Quinn, 2011). Kebijakan aliran kas perusahaan untuk mengatur modal kerja dalam bentuk piutang dari pelanggan, persediaan dan kas untuk pembayaran kepada suplier, berhubungan dengan kinerja keuangan yang lebih baik (Richards dan Laughlin, 1980 ; Stewart, 1995). Industri telah menerima efektifitas manajemen aliran kas sebagai sarana untuk meningkatan kinerja dan meningkatkan nilai suatu perusahaan (Ebben dan Johnson, 2011).

Teori manajemen modal kerja menganjurkan bahwa perusahaan dapat meningkatkan likuiditas dan posisi kompetitif dengan mengatur aliran kas mereka (Brewer and Speh, 2000 ; Farris and Hutchison, 2002, 2003; Moss and Stine, 1993; Stewart, 1995). Selanjutnya, kemampuan perusahaan untuk mengubah bahan baku menjadi kas melalui penjualan mencerminkan kemampuan perusahaan untuk menghasilkan pengembalian secara efektif dari investasinya (Gunasekaran et.al, 2004). Efisiensi manajemen modal kerja adalah bagian mendasar dari strategi perusahaan secara keseluruhan dalam menciptakan nilai perusahaan (Deloof, 2003). Perusahaan dengan pengelolaan modal kerja yang efektif dan efisien dapat dilihat dari aliran kasnya yang semakin pendek. Perusahaan yang mempunyai aliran kas yang singkat menggambarkan perusahaan mampu menagih piutangnya dengan cepat dan membayar suplier lebih lama namun dengan tetap menjaga kredibilitasnya. Hal ini akan memberikan pengaruh yang maksimal pada likuiditas dan profitabilitas.

Manajemen aliran kas diukur dengan menggunakan (i) days of sales outstanding (DSO) yaitu lamanya waktu rata-rata yang diperlukan untuk menagih penjualan kredit (Subramanyam, 2010); (ii) days of inventory outstanding (DIO) yaitu perubahan tingkat persediaan perusahaan yang menggambarkan rata-rata waktu barang disimpan dalam persediaan sebelum terjual (Subramanyam, 2010); (iii) cash conversion cycle (CCC) yaitu lamanya waktu atau periode yang dibutuhkan untuk mengkonversi setiap kas yang dikeluarkan menjadi aliran kas masuk dalam 
kegiatan operasional perusahaan (Brigham dan Houston, 2001); (iv) operating cash cycle (OCC) yaitu lamanya kas perusahaan terikat dalam modal kerja sebelum uang itu akhirnya diterima kembali ketika pelanggan membayar untuk produk yang dijual atau jasa yang telah diberikan (Churchill dan Mullins, 2001).

Penelitian yang dilakukan oleh Kroes dan Manikas (2014) menemukan bahwa DSO, DIO dan OCC berpengaruh negatif signifikan terhadap kinerja perusahaan sementara CCC tidak berpengaruh terhadap kinerja perusahaan. Sedangkan penelitian yang dilakukan oleh Gill, Biger dan Mathur (2010) menyatakan bahwa DSO tidak berpengaruh signifikan terhadap profitabilitas dan CCC berpengaruh positif signifikan terhadap profitabilitas. Penelitian yang dilakukan oleh Capkun et al., (2009) menemukan hasil bahwa DIO berpengaruh negatif signifikan terhadap likuiditas dan kinerja keuangan, sementara itu penelitian yang dilakukan oleh Setyanto dan Pematasari (2014) menemukan bahwa CCC berpengaruh signifikan terhadap nilai perusahaan. Selanjutnya penelitian yang dilakukan oleh Churchill dan Mullins (2001) OCC berpengaruh signifikan terhadap kinerja perusahaan.

Penelitian ini menggali hubungan antara perubahan dalam ukuran aliran kas dan perubahan pada nilai perusahaan dari waktu ke waktu secara longitudinal. Longitudinal merupakan penelitian yang memaki data dengan rentang waktu yang panjang, panjang waktu yang dimaksud bersifat sangat relatif. Tetapi, penekanan riset longitudinal sebenarnya pada perluasan atau perpanjangan dari survey yang dilakukan, perpanjangan tersebut bersifat periodik (Fress, 2004). Pendekatan ini akan memungkinkan perusahaan untuk menentukan ukuran aliran kas mana yang harus diawasi, diatur dan diperiksa untuk meningkatkan nilai perusahaan. Tujuan penelitian ini adalah untuk memberikan bukti secara empiris mengenai pengaruh penurunan atau peningkatan jumlah hari dalam penjualan (DSO), jumlah hari dalam persediaan (DIO), cash conversion cycle (CCC) dan operating cash cycle (OCC) terhadap nilai perusahaan satu tahun kedepan.

\section{REVIU LITERATUR DAN HIPOTESIS \\ Teori Manajemen Modal Kerja}

Pengertian modal kerja atau working capital adalah modal yang digunakan untuk membiayai operasional perusahaan sehari-hari yang dimaksudkan untuk menghasilkan pendapatan jangka pendek (current income). Dengan kata lain bahwa modal kerja merupakan kelebihan aktiva lancar diatas hutang lancar. Selisih lebih ini disebut modal kerja bersih (Net working capital). Sedangkan total dari aktiva lancar disebut modal bruto (gross working capital) (Kasmir, 2010).

Teori manajemen modal kerja menganjurkan bahwa perusahaan dapat meningkatkan likuiditas dan posisi kompetitif dengan mengatur aliran kas mereka (Farris dan Hutchison, 2003). Manajemen modal kerja berkaitan dengan bagaimana mengelola semua variabel yang ada di aktiva lancar dan hutang lancar sehingga diharapkan terjadi efisiensi didalam pengelolaan modal kerja perusahaan yang pada akhirnya memberikan dampak positif terhadap profitabilitas dan nilai perusahaan.

\section{Nilai Perusahaan}

Nilai perusahaan merupakan penilaian investor terhadap keberhasilan suatu perusahaan yang berhubungan dengan harga saham (Sujoko dan Soebianto, 2007). Menurut Dipanala (2018) nilai perusahaan merupakan salah satu cara untuk melihat apakah perusahaan tersebut sudah berada di posisi baik atau belum. Perusahaan memiliki nilai yang baik menunjukkan bahwa 
posisi para pemegang saham juga sedang dalam kondisi makmur. Tingginya nilai perusahaan membuat keinginan investor untuk membeli saham pada perusahaan tersebut juga semakin besar.

Keown (2004) menyatakan nilai perusahaan merupakan nilai pasar hutang dan ekuitas perusahaan yang beredar. Dengan demikian, akumulasi dari jumlah ekuitas perusahaan dengan hutang perusahaan dapat menggambarkan nilai suatu perusahaan. Harga saham yang tinggi akan meningkatkan nilai perusahaan. Nilai perusahaan yang meningkat akan membuat pasar percaya tidak hanya pada kinerja perusahaan saat ini namun juga pada prospek perusahaan dimasa yang akan datang. Banyak kebijakan yang diambil oleh pihak manajemen sebagai langkah untuk meningkatkan nilai perusahaan melalui peningkatan kemakmuran pemilik dan para pemegang saham yang terlihat pada harga saham suatu perusahaan (Brigham dan houston, 2001).

\section{Manajemen Aliran Kas}

Days of sales outstanding (DSO)

Days of sales outstanding (DSO) yaitu mengukur jumlah hari yang dibutuhkan secara rata-rata untuk menagih piutang berdasarkan saldo piutang akhir periode. Ukuran ini mewakili rata-rata waktu ketika terjadinya penjualan sampai pendapatan diterima, atau disebut juga dengan jumlah hari untuk menagih piutang (Subramanyam, 2010)

\section{Days of inventory outstanding (DIO)}

Days of inventory outstanding (DIO) yaitu mengukur jumlah hari yang dibutuhkan untuk menjual persediaan. Pengukuran ini menjelaskan waktu rata-rata barang disimpan dalam persediaan sebelum dijual, atau disebut juga dengan jumlah hari penjualan dalam persediaan (Subramanyam, 2010).

\section{Cash conversion cycle $(C C C)$}

Siklus konversi kas (Cash conversion cycle) adalah jangka waktu bersih antara pengeluaran kas aktual atas pembelian sumberdaya produktif perusahaan dan pemulihan akhir penerimaan kas dari penjualan produk, pada dasarnya ini mengukur hari persediaan dan piutang versus hari-hari hutang. Menetapkan periode waktu yang disyaratkan untuk mengubah satu rupiah pengeluaran kas menjadi satu rupiah arus kas masuk dari kegiatan operasi suatu perusahaan. (Richards dan Laughlin, 1980).

\section{Operating cash cycle (OCC)}

Setiap perusahaan memiliki siklus kas operasi (operating cash cycle). Siklus kas operasi perusahaan yaitu lamanya kas perusahaan terikat dalam modal kerja sebelum uang itu akhirnya diterima kembali ketika pelanggan membayar untuk produk yang dijual atau jasa yang telah diberikan, lamanya operating cash cycle perusahaan ditentukan oleh sejumlah faktor termasuk ketentuan pembayaran yang diberikan perusahaan kepada pelanggan dan waktu yang diberikan suplier kepada perusahaan (Shin dan Soenen, 1998).

\section{Pengaruh Days of Sales Outstanding (DSO) terhadap Nilai Perusahaan}

Kemampuan perusahaan untuk menerima pembayaran dari pelanggan atas barang yang telah dikirim atau jasa yang telah diberikan secara tepat waktu dapat meningkatkan likuiditas perusahaan (Gallinger, 1997 dalam Kroes dan Manikas, 2014). Kas yang diterima dari pelanggan dapat digunakan untuk berinvestasi dalam aktivitas yang bertujuan untuk promosi penjualan tambahan. Oleh karena itu semakin cepat pembayaran diterima (semakin singkat DSO 
perusahaan) semakin besar peluang perusahaan untuk melakukan kegiatan tersebut (Bauer, 2007 dalam Kroes dan Manikas, 2014). Meskipun mempersingkat DSO dapat terlihat tidak menguntungkan bagi pelanggan, perusahaan sering memanfaatkan insentif, seperti potongan pembayaran dalam upaya untuk mempersingkat siklus DSO perusahaan tanpa merusak hubungan dengan pelanggan (Moran, 2011).

Ketika perusahaan memperpanjang periode piutang melalui penjualan kredit, resiko menagih piutang meningkat secara signifikan. Berdasarkan faktor tersebut, teori manajemen modal kerja umumnya memprediksi bahwa DSO yang lebih singkat dapat meningkatkan kinerja keuangan perusahaan yang pada akhirnya dapat meningkatkan nilai perusahaan (Churchill dan Mullins, 2001). Hal ini berarti periode days of sales outstanding (DSO) yang lebih singkat dapat meningkatkan nilai perusahaan.

H1: Jumlah hari dalam penjualan (DSO) berpengaruh negatif terhadap nilai perusahaan satu tahun kedepan.

\section{Pengaruh Days of Inventory Outstanding (DIO) terhadap Nilai Perusahaan}

Menurut Shah dan Shin (2007) Hubungan antara persediaan dan kinerja keuangan tidak sederhana. Persediaan adalah investasi yang ditujukan untuk mendapatkan keuntungan dari penjualan yang dilakukan kepada pelanggan. Sebagian besar perusahaan mempertahankan tingkat persediaan tertentu (Subramanyam, 2010). Perusahaan biasanya harus menyediakan barang untuk pelanggan mereka secara tepat waktu, artinya kekurangan dalam persediaan dapat menyebabkan penurunan pelayanan pada pelanggan dan volume penjualan akan turun dibawah tingkat yang dapat dicapai. Namun dengan mengadakan persediaan, akan mengakibatkan kas tidak tersedia dalam perusahaan karena diinvestasikan dalam persediaan dan perusahaan terpaksa untuk mengeluarkan biaya penyimpanan, asuransi, pajak, keusangan dan kerusakan fisik. Oleh karena itu penurunan persediaan dapat mengurangi biaya tersebut dan mengembalikan kas yang dapat diinvestasikan kembali untuk meningkatkan penjualan (Kroes dan Manikas, 2014).

Periode penyimpanan persediaan yang lebih singkat (DIO yang lebih rendah) umumnya berhubungan dengan peningkatan likuiditas dan kinerja keuangan perusahaan yang lebih baik (Koumanakos, 2009). Sesuai dengan konsep manajemen modal kerja, dimana perusahaan dengan penerapan modal kerja yang baik akan memiliki tingkat likuiditas dan profitabilitas yang tinggi (Setyanto dan Permatasari, 2014). Perusahaan dengan pofitabilitas yang baik memiliki kesempatan untuk bertumbuh secara konsisten, dimana pertumbuhan tersebut pada akhirnya akan meningkatkan nilai perusahaan (Varaiya et al., 1987). Hal tersebut berarti days of inventory outstanding (DIO) yang lebih singkat dapat meningkatkan nilai perusahaan.

H2: Jumlah hari dalam persediaan (DIO) berpengaruh negatif terhadap nilai perusahaan satu tahun kedepan

\section{Pengaruh Cash Conversion Cycle (CCC) terhadap Nilai Perusahaan}

Cash Conversion Cycle (CCC) yang lebih singkat secara teoritis berhubungan dengan peningkatan likuiditas perusahaan dan peningkatan kinerja keuangan perusahaan (Garcia dan Martinez, 2007). Siklus konversi kas yang pendek menunjukkan bahwa perusahaan mengelola dan memproses inventaris lebih cepat dan memperlambat pembayaran kas kepada pemasok. Hal ini dapat meningkatkan efisiensi operasional internal, menghasilkan profitabilitas yang tinggi, meningkatkan nilai sekarang dari arus kas dan meningkatkan nilai pasar suatu perusahaan (Nobanee dan Abdullatif, 2010). 
Siklus konversi kas yang singkat dapat dilakukan dengan mengurangi periode penagihan piutang, mengurangi periode penjualan persediaan dan menambah atau memperpanjang periode pembayaran kredit (Linh dan Mohanllingam, 2018). Sesuai dengan konsep manajemen modal kerja, dimana perusahaan dengan penerapan modal kerja yang baik akan memiliki tingkat likuiditas dan profitabilitas yang tinggi. Peningkatan profitabilitas perusahaan melalui siklus konvesi kas yang singkat dapat terjadi karena perusahaan mampu mengumpulkan kas yang diperlukan untuk kegiatan operasional dengan lebih cepat. Pada saat profitabilitas perusahaan mengalami peningkatan, tidak menutup kemungkinan bahwa jumlah deviden yang diterima oleh para pemegang saham juga akan mengalami peningkatan. Adanya peningkatan dalam jumlah deviden mengindikasikan bahwa tingkat kesejahteraan pemegang saham perusahaan semakin tinggi dan pada akhirnya perusahaan yang bersangkutan akan memiliki nilai yang tinggi dimata investor (Setyanto dan Permatasari, 2014).

H3: Cash conversion cycle (CCC) berpengaruh negatif terhadap nilai perusahaan satu tahun kedepan

\section{Operating Cash Cyle (OCC) terhadap Nilai Perusahaan}

Arus kas operasi juga merupakan salah satu faktor yang sangat penting dalam menciptakan nilai perusahaan. Menurut Puspitasari (2010) untuk memaksimalisasi laba dan nilai perusahaan sangatlah tidak mudah, diperlukan perencanaan dan tata kelola perusahaan yang baik untuk mencapai tujuan perusahaan tersebut, karenanya perusahaan harus mampu memanfaatkan sumber daya melalui perbaikan kinerja manajemen yaitu melalui penggunaan arus kas operasi semaksimal mungkin didalam siklus operasi (operating cash cycle) serta melakukan efisiensi terhadap biaya-biaya yang dikeluarkan oleh perusahaan dalam proses produksi, sehingga hal tersebut dapat meningkatkan nilai perusahaan.

Operating Cash Cycle (OCC) yang lebih singkat juga berhubungan dengan likuiditas dan kinerja perusahaan yang lebih baik (Churchill dan Mullins, 2001). Jika perusahaan diberi lebih banyak waktu untuk membayar pemasoknya, perusahaan dapat mengurangi operating cash cycle dengan menunda pengeluaran kas. Sebaliknya, jika perusahaan memberi pelanggan lebih banyak waktu untuk membayar piutang, hal ini dapat memperpanjang operating cash cycle karena perusahaan harus menunggu lebih lama untuk mendapatkan kas, operating cash cycle yang lebih pendek menunjukkan bahwa kas perusahaan terikat untuk jangka waktu yang lebih pendek yang umumnya lebih ideal dari perspektif arus kas (Churchill dan Mullins, 2001).

Melalui kebijakan manajemen modal kerja yang efisien berarti perusahaan menerapkan siklus kas operasi yang singkat. Siklus kas operasi yang singkat mengindikasikan bahwa kas yang terikat dalam modal kerja lebih sedikit, sehingga tersedianya kas yang diperlukan untuk kegiatan operasional perusahaan. Oleh karena itu perusahaan tidak perlu memakai maupun mencari tambahan sumber pendanaan yang berasal dari luar perusahaan. Ketika perusahaan tidak membutuhkan pendanaan tambahan dari pihak lain maka hal itu berarti tidak ada tambahan biaya yang harus dikeluarkan untuk pinjaman dana, sehingga selanjutnya keuntungan perusahaan akan dapat meningkat yang pada akhirnya dapat meningkatkan nilai perusahaan.

H4: Operating cash cycle (OCC) berpengaruh negatif terhadap nilai perusahaan satu tahun kedepan 


\section{Kerangka Konseptual}

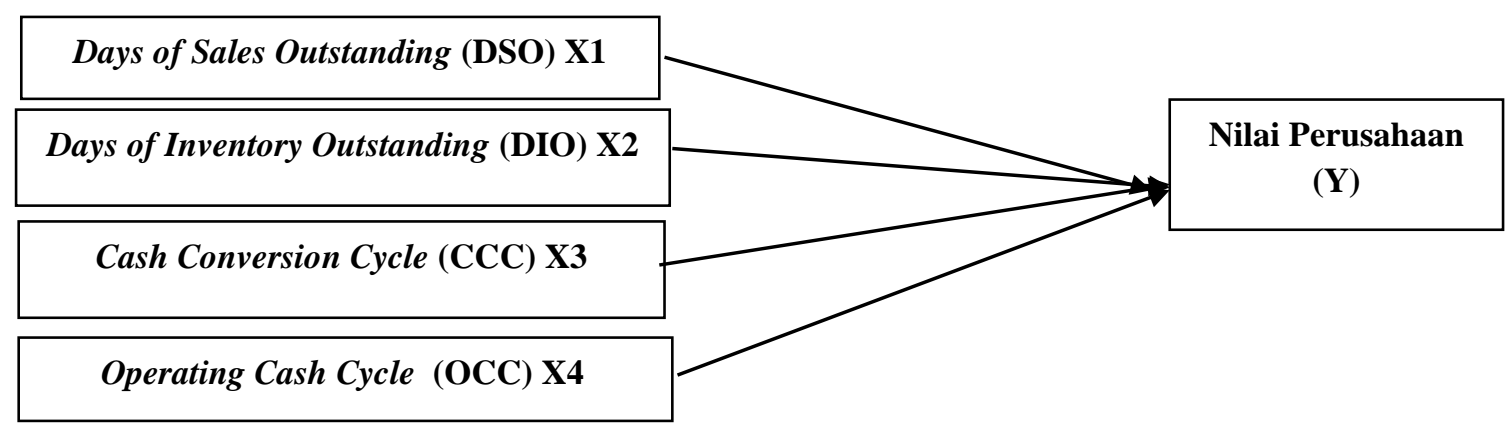

\section{Gambar 1. Kerangka Konseptual}

\section{METODE PENELITIAN}

\section{Sampel dan Jenis Penelitian}

Penelitian ini tergolong penelitian kausatif dengan pendekatan kuantitatif. Penelitian kausatif merupakan penelitian untuk menganalisis pengaruh variabel dengan variabel lainnya bertujuan untuk melihat seberapa jauh variabel bebas (independen) mempengaruhi variabel terikat (dependen). Populasi dalam penelitian ini adalah semua perusahaan manufaktur yang terdaftar di Bursa Efek Indonesia tahun 2017 dan 2018 yang berjumlah 175 perusahaan. Metode pengambilan sampel pada penelitian ini menggunakan metode purposive sampling yaitu pengambilan sampel sesuai dengan kriteria tertentu, dengan rincian sebagai berikut:

Tabel 1

Kriteria Pemilihan Sampel

\begin{tabular}{lc}
\hline \multicolumn{1}{c}{ Keterangan } & Jumlah \\
\hline \hline Perusahaan manufaktur yang terdaftar di BEI 2018 & 175 \\
\hline $\begin{array}{l}\text { Perusahaan manufaktur yang tidak menyajikan laporan } \\
\text { keuangan triwulanan secara lengkap selama periode penelitian }\end{array}$ & $(43)$ \\
\hline $\begin{array}{l}\text { Perusahaan manufaktur yang tidak menggunakan mata uang } \\
\text { rupiah sebagai mata uang fungsional }\end{array}$ & $(31)$ \\
\hline Total Sampel & $\mathbf{1 0 1}$ \\
\hline Sumber : Data olahan peneliti (2019)
\end{tabular}

\section{Jenis, Sumber dan Teknik Pengumpulan Data}

Jenis data yang digunakan dalam penelitian ini adalah data dokumenter dan data sekunder. Metode pengumpulan data yang digunakan dalam penelitian ini adalah studi pustaka dan studi dokumentasi.

\section{Variabel Penelitian dan Pengukuran}

Variabel dependen pada penelitian ini adalah nilai perusahaan. Nilai perusahaan pada penelitian ini akan diukur dengan menggunakan rasio Tobin's $Q$ yang dikembangkan Kallapur dan Trombley dalam Fahrizal (2015).

$$
\text { Tobin's } Q=\frac{\text { Market Value of Equity+Total Debt }}{\text { Total Asset }}
$$


Keterangan :

Market value of equity : harga penutupan saham dikali dengan jumlah saham yang beredar

Total Debt

: nilai buku dari total hutang

Variabel independen dalam penelitian ini adalah manajemen aliran kas. Pengukuran manajemen aliran kas dalam penelitian ini merujuk pada rumus yang digunakan oleh Subramanyam (2010) dan Kroes dan Manikas (2014) yaitu sebagai berikut :

Days of Sales Outstanding (DSO)

Days of Sales Outstanding (DSO) yaitu mengukur jumlah hari yang dibutuhkan secara rata-rata untuk menagih piutang berdasarkan saldo akhir piutang dalam suatu periode. Dengan rumus sebagai berikut:

$$
\text { DSO }=\frac{\text { Piutang akhir periode kuartal }}{\text { Penjualan }} \times 360
$$

\section{Days Of Inventory Outstanding (DIO)}

Days Of Inventory Outstanding (DIO) yaitu mengukur jumlah hari yang dibutuhkan untuk menjual persediaan. Pengukuran ini menjelaskan waktu rata-rata barang disimpan dalam persediaan sebelum dijual. Dengan rumus sebagai berikut:

$$
\mathrm{DIO}=\frac{\text { Persediaan akhir periode kuartal }}{\text { Harga Pokok Penjualan }} \times 360
$$

\section{Cash Conversion Cycle (CCC)}

Cash Conversion Cycle (CCC) adalah durasi (dalam hari) yang diperlukan untuk mengubah kas yan diinvestasikan dalam persediaan kedalam kas yang dikumpulkan dari pelanggan. Metrik CCC merupakan kombinasi dari tiga metrik arus kas untuk memberikan indikator keseluruhan posisi kas suatu perusahaan. Dengan rumus sebagai berikut:

$$
\begin{gathered}
\mathrm{CCC}=(\text { DSO perkuartal }+ \text { DIO perkuartal })-(\text { DPO perkuartal }) \\
\mathrm{DPO}=\frac{\text { Hutang usaha akhir periode kuartal }}{\text { harga pokok penjualan }} \times 360
\end{gathered}
$$

\section{Operating Cash Cycle (OCC)}

Operating Cash Cycle (OCC) adalah durasi (dalam hari) yang berhubungan dengan kas dalam modal kerja sebelum pemabayaran diterima dari pelanggan. Metrik OCC hanya menggunakan sebagian metrik CCC. Dengan rumus sebagai berikut:

\section{Metode Analisis Data}

$$
\text { OCC = DSO perkuartal }+ \text { DIO perkuartal }
$$

Analisis data pada penelitian ini diuji menggunakan program e-views. Dengan menggunakan analisis deskriptif dan analisis induktif, model regresi yang digunakan yaitu : Persamaan 1 :

$\begin{aligned} \text { TOBIN'S_Q } & \alpha+\beta_{1}\left(\mathrm{DSO}_{\mathrm{it}}\right)+\beta_{2}\left(\Delta \mathrm{DSO}_{\mathrm{it}-1}\right)+\beta_{3}\left(\Delta \mathrm{DSO}_{\mathrm{it}-2}\right)+ \\ & \beta_{4}\left(\Delta \mathrm{DSO}_{\mathrm{it}-3}\right)+\beta_{5}\left(\Delta \mathrm{DSO}_{\mathrm{it}-4}\right)+\beta_{6}\left(\mathrm{DIO}_{\mathrm{it}}\right)+\beta_{7}\left(\Delta \mathrm{DIO} \mathrm{it}_{\mathrm{it}}\right. \\ & 1)+\beta_{8}(\Delta \mathrm{DIO} \mathrm{it-2})+\beta_{9}\left(\Delta \mathrm{DIO}_{\mathrm{it}-3}\right)+\beta_{10}(\Delta \mathrm{DIOit})+ \\ & \beta_{11}(\mathrm{DPOit})+\beta_{12}(\Delta \mathrm{DPOit}-1)+\beta_{13}(\Delta \mathrm{DPOit}-2)+ \\ & \beta_{14}(\Delta \mathrm{DPOit}-3)+\beta_{15}(\Delta \mathrm{DPOit}-4)+\mathrm{e}_{\mathrm{it}}\end{aligned}$


DSOit $=$ DSO kuartal saat ini, $\triangle$ DSOit-1 = perubahan DSO kuartal sebelumnya, $\Delta$ DSOit-2 = perubahan DSO dua kuartal sebelumnya, $\triangle$ DSOit-3 = perubahan DSO tiga kuartal sebelumnya, $\triangle$ DSOit-4 = perubahan DSO empat kuartal sebelumnya, DIOit $=$ DIO kuartal saat ini, $\Delta$ DIOit-1 $=$ perubahan DIO kuartal sebelumnya, $\Delta$ DIOit- $2=$ perubahan DIO dua kuartal sebelumnya, $\triangle$ DIOit-3 = perubahan DIO tiga kuartal sebelumnya, $\triangle$ DIOit-4 = perubahan DIO empat kuartal sebelumnya, DPOit $=$ DPO kuartal saat ini, $\triangle$ DPOit-1 = perubahan DPO kuartal sebelumnya, $\triangle$ DPOit- $2=$ perubahan DPO dua kuartal sebelumnya, $\triangle$ DPOit-3 = perubahan DPO tiga kuartal sebelumnya, $\triangle$ DPOit-4 = perubahan DPO empat kuartal sebelumnya.

Persamaan 2 :

TOBIN'S_Qit $=\quad \alpha+\beta_{1}\left(\mathrm{CCC}_{\mathrm{it}}\right)+\beta_{2}\left(\Delta \mathrm{CCC}_{\mathrm{it}-1}\right)+\beta_{3}\left(\Delta \mathrm{CCC}_{\mathrm{it}-2}\right)+$

$$
\beta_{4}\left(\Delta \mathrm{CCC}_{\mathrm{it}-3}\right)+\beta_{5}\left(\Delta \mathrm{CCC}_{\mathrm{it}-4}\right)+e_{i t}
$$

CCCit = CCC kuartal saat ini, $\triangle$ CCCit-1 = perubahan CCC kuartal sebelumnya, $\triangle$ CCCit-2 = perubahan CCC dua kuartal sebelumnya, $\Delta$ CCCit-3 = perubahan CCC tiga kuartal sebelumnya, $\Delta$ CCCit-4 = perubahan CCC empat kuartal sebelumnya.

Persamaan 3 :

TOBIN'S_Qit $=\quad \alpha+\beta_{1}\left(\mathrm{OCC}_{\mathrm{it}}\right)+\beta_{2}\left(\Delta \mathrm{OCC}_{\mathrm{it}-1}\right)+\beta_{3}\left(\Delta \mathrm{OCC}_{\mathrm{it}-2}\right)+$ $\beta_{4}\left(\Delta \mathrm{OCC}_{\mathrm{it}-3}\right)+\beta_{5}\left(\Delta \mathrm{OCC}_{\mathrm{it}-4}\right)+e_{i t}$

OCCit $=$ OCC kuartal saat ini, $\triangle$ OCCit-1 = perubahan OCC kuartal sebelumnya, $\triangle$ OCCit-2 = perubahan OCC dua kuartal sebelumnya, $\triangle$ OCCit-3 = perubahan OCC tiga kuartal sebelumnya, $\triangle$ OCCit-4 = perubahan OCC empat kuartal sebelumnya.

\section{HASIL DAN PEMBAHASAN Analisis Deskrptif}

Tabel 2

Statistik Deskriptif Perusahaan Manufaktur tahun 2017-2018

\begin{tabular}{|c|c|c|c|c|c|}
\hline \multicolumn{6}{|c|}{ PERSAMAAN 1} \\
\hline Variabel & Mean & Median & Maximum & Minimum & Std. Dev \\
\hline Tobin'sQ & 18830.74 & 10029.00 & 354003.0 & 3237.000 & 34650.76 \\
\hline DSOit & 30768.57 & 31811.50 & 50045.00 & 3836.000 & 7170.082 \\
\hline DSOit-1 & -2.084 .653 & -1.700 .000 & 35.00000 & -1.710 .000 & 20.98616 \\
\hline DSOit-2 & -6.677 .723 & -5.500 .000 & 36.00000 & -5.270 .000 & 60.85383 \\
\hline DSOit-3 & -2.941 .584 & -2.400 .000 & 41.00000 & -2.550 .000 & 28.73182 \\
\hline DSOit-4 & -0.485149 & 0.000000 & 47.00000 & -7.500 .000 & 12.09343 \\
\hline DIOit & 44.65347 & 36.00000 & 159.0000 & 0.000000 & 28.83335 \\
\hline DIOit-1 & -3.012 .376 & -2.550 .000 & 88.00000 & -1.270 .000 & 24.51397 \\
\hline DIOit-2 & -1.073 .762 & -8.400 .000 & -4.000 .000 & -4.350 .000 & 72.10224 \\
\hline DIOit-3 & -4.286 .139 & -3.500 .000 & 40.00000 & -1.590 .000 & 30.99592 \\
\hline DIOit-4 & 0.386139 & 1.000000 & 79.00000 & -1.310 .000 & 15.98536 \\
\hline \multicolumn{6}{|c|}{ PERSAMAAN 2} \\
\hline & Mean & Median & Maximum & Minimum & Std. Dev \\
\hline Tobin'sQ & 18830.74 & 10029.00 & 354003.0 & 3237.000 & 34650.76 \\
\hline CCCit & 50.34158 & 41.00000 & 186.0000 & -1.200 .000 & 37.58343 \\
\hline CCCit-1 & -3.370 .792 & -3.000 .000 & 378.0000 & -2.440 .000 & 45.21204 \\
\hline CCCit-2 & -1.260 .050 & -1.065 .000 & 99.00000 & -5.860 .000 & 100.2820 \\
\hline CCCit-3 & -5.271 .287 & -4.750 .000 & 49.00000 & -2.960 .000 & 43.44937 \\
\hline CCCit-4 & 0.633663 & 1.000000 & 100.0000 & -1.380 .000 & 18.49309 \\
\hline \multicolumn{6}{|c|}{ PERSAMAAN 3} \\
\hline & Mean & Median & Maximum & Minimum & Std. Dev \\
\hline Tobin'sQ & 18830.74 & 10029.00 & 354003.0 & 3237.000 & 34650.76 \\
\hline OCCit & 71.80198 & 64.00000 & 226.0000 & 6.000000 & 37.91113 \\
\hline OCCit-1 & -5.098 .515 & -4.250 .000 & 69.00000 & -2.430 .000 & 34.84471 \\
\hline
\end{tabular}




\begin{tabular}{lccccc}
\hline OCCit-2 & -1.740 .891 & -1.520 .000 & -2.000 .000 & -5.870 .000 & 101.1054 \\
OCCit-3 & -7.230 .198 & -6.600 .000 & 25.00000 & -3.170 .000 & 45.31145 \\
OCCit-4 & -0.133663 & 1.000000 & 100.0000 & -1.480 .000 & 20.79291 \\
\hline
\end{tabular}

Sumber : Olahan Data Eviews9 2020

Pada tabel diatas menjelaskan variabel-variabel dalam penelitian ini. Nilai perusahaan pada persamaan pertama, kedua dan ketiga menunjukkan rata-rata sebesar 18830,74 dengan nilai minimum sebesar 3237,000 dan nilai maksimum sebesar 354003,0. Variabel bebas yang pertama adalah days of sales outstanding dengan nilai mean sebesar 30768,57 sedangkan nilai minimumnya adalah 3836,00 dan nilai maksimum sebesar 50045,00. Variabel bebas yang kedua adaalah days of inventory outstanding yang memiliki nilai mean sebesar 44,65347 dengan nilai minimumnya 0,000 dan nilai maksimumnya sebesar 159,0000. Variabel bebas yang ketiga adalah cash conversion cycle dengan nilai mean sebesar 50,341548 sedangkan nilai minimumnya adalah -1,200,000 dan nilai maksimum sebesar 186,000. Dan variabel bebas yang keempat adalah operating cash cycle yang memiliki nilai mean sebesar 71,80198 dengan nilai minimumya 6,000 dan nilai makimumnya sebesar 226,0000.

\section{Analisis Induktif}

\section{Analisis Model Regresi}

Sesuai dengan hasil uji Chow Test, uji Hausmant Test metode yang terpilih untuk digunakan dalam penelitian ini adalah Random Effect Model, dan tidak perlu melakukan uji asumsi klasik.

Tabel 3

Data hasil Uji Chow-Test

\begin{tabular}{cccc}
\hline & & Cross-section Chi-squre & \\
\hline Model Penelitian & Statistic & d.f. & Prob. \\
\hline Persamaan 1 & 807.748162 & 100 & 0.0000 \\
Persamaan 2 & 800.866864 & 100 & 0.0000 \\
Persamaan 3 & 795.031865 & 100 & 0.0000 \\
\hline
\end{tabular}

Sumber : Olahan Data Eviews9 2020

\section{Tabel 4}

Data hasil Uji Hausman-Test

\begin{tabular}{cccc}
\hline & & Cross-section random \\
\hline Model Penelitian & Chi-Sq. Statistic & Chi-Sq. d.f. & Prob. \\
\hline Persamaan 1 & 17.498366 & 15 & 0.2900 \\
Persamaan 2 & 10.478297 & 5 & 0.0628 \\
Persamaan 3 & 8.803486 & 5 & 0.1172 \\
\hline
\end{tabular}

\section{Model Regresi Panel}

Adapun hasil regresi panel dengan menggunakan pendekatan random effect model untuk regresi persamaan pertama yang digunakan dalam penelitian ini yaitu: 
Tabel 5

Hasil Estimasi Regresi Panel dengan Model Random Effect Persamaan 1

\begin{tabular}{ccccc}
\hline Variable & Coefficient & Std. Error & t-Statistic & Prob. \\
C & 53228.95 & 11512.74 & 4.623481 & 0.0000 \\
\hline DSOit & -0.646600 & 0.356525 & -1.813619 & 0.0713 \\
DSOit-1 & 151.4220 & 89.65690 & 1.688905 & 0.0929 \\
DSOit-2 & -107.1727 & 45.94167 & -2.332798 & 0.0207 \\
DSOit-3 & 163.5848 & 47.33111 & 3.456178 & 0.0007 \\
DSOit-4 & -178.9310 & 113.8265 & -1.571963 & 0.1177 \\
DIOit & -231.6019 & 90.91412 & -2.547480 & 0.0117 \\
DIOit-1 & -53.89389 & 56.43628 & -0.954951 & 0.3408 \\
DIOit-2 & -31.98093 & 48.24090 & -0.662942 & 0.5082 \\
DIOit-3 & 93.81670 & 73.72618 & 1.272502 & 0.2048 \\
DIOit-4 & -38.66456 & 86.12644 & -0.448928 & 0.6540 \\
DPOit & -157.8164 & 141.5272 & -1.115096 & 0.2662 \\
DPOit-1 & 4.396431 & 22.62125 & 0.194350 & 0.8461 \\
DPOit-2 & 68.37300 & 44.80561 & 1.525992 & 0.1287 \\
DPOit-3 & -125.0838 & 72.86120 & -1.716742 & 0.0877 \\
DPOit-4 & 219.9423 & 119.1515 & 1.845904 & 0.0665 \\
\hline R-squared & 0.191397 & Mean dependent var & 2669.403 \\
Adjusted R-squared & 0.126187 & S.D. dependent var & 7291.025 \\
F-statistic & 2.935085 & Durbin-Watson stat & 1.832563 \\
Prob(F-statistic) & 0.000336 & & & \\
\hline
\end{tabular}

Nilai konstanta pada hasil pengujian ini dapat dilihat pada tabel 5 diatas, dimana nilai konstanta yang diperoleh sebesar 53228,95 ini artinya jika variabel DSOit, DSOit-1, DSOit-2, DSOit-3, DSOit-4 (X1), DIOit, DIOit-1, DIOit-2, DIOit-3, DIOit-4 (X2) dan DPOit, DPOit-1, DPOit-2, DPOit-3, DPOit-4 bernilai nol (0) maka nilai perusahaan akan mengalami peningkatan sebesar 53228,95. nilai koefisien regresi DSOit sebesar -0,6466 ini menandakan bahwa setiap penambahan satu satuan DSOit akan menurunkan nilai perusahaan sebesar -0,6466. Nilai koefisien regresi DSOit-1 sebesar 151,42 ini menandakan bahwa setiap penambahan satu satuan DSOit-1 akan meningkatkan nilai perusahaan sebesar 151,42. Nilai koefisien regresi DSOit-2 sebesar -107,17 ini menandakan bahwa setiap penambahan satu satuan DSOit-2 akan menurunkan nilai perusahaan sebesar -107,17. Nilai koefisien regresi DSOit-3 sebesar 163,58 ini menandakan bahwa setiap penambahan satu satuan DSOit-3 akan meningkatkan nilai perusahaan sebesar 163,58. Nilai koefisien regresi DSOit-4 sebesar -178,93 ini menandakan bahwa setiap penambahan satu satuan DSOit-4 akan menurunkan nilai perusahaan sebesar -178,93.

Nilai koefisien regresi DIOit sebesar -231,60 ini menandakan bahwa setiap penambahan satu satuan DSOit akan menurunkan nilai perusahaan sebesar -231,60. Nilai koefisien regresi DIOit-1 sebesar $-53,89$ ini menandakan bahwa setiap penambahan satu satuan DIOit-1 akan menurunkan nilai perusahaan sebesar -53,89. Nilai koefisien regresi DIOit-2 sebesar $-31,98$ ini menandakan bahwa setiap penambahan satu satuan DIOit-2 akan menurunkan nilai perusahaan sebesar -31,98. Nilai koefisien regresi DIOit-3 sebesar 93,81 ini menandakan bahwa setiap penambahan satu satuan DIOit-3 akan meningkatkan nilai perusahaan sebesar 93,81. Nilai koefisien regresi DIOit-4 sebesar -38,66 ini menandakan bahwa setiap penambahan satu satuan DIOit-4 akan menurunkan nilai perusahaan sebesar -38,66. 
Hasil regresi panel dengan menggunakan pendekatan random effect model untuk regresi persamaan kedua.

Tabel 6

Hasil Estimasi Regresi Panel dengan Model Random Effect Persamaan 2

\begin{tabular}{ccccc}
\hline Variable & Coefficient & Std. Error & t-Statistic & Prob. \\
\hline C & 28014.13 & 4680.309 & 5.985531 & 0.0000 \\
CCCit & -155.6784 & 74.94116 & -2.077342 & 0.0391 \\
CCCit-1 & -0.142187 & 20.54924 & -0.006919 & 0.9945 \\
CCCit-2 & -37.73509 & 23.57637 & -1.600547 & 0.1111 \\
CCCit-3 & 114.3222 & 34.37750 & 3.325495 & 0.0011 \\
CCCit-4 & -125.6928 & 51.94328 & -2.419808 & 0.0164 \\
R-squared & 0.118539 & Mean dependent var & & 2674.772 \\
Adjusted R-squared & 0.096053 & S.D. dependent var & & 7297.521 \\
F-statistic & 5.271643 & Durbin-Watson stat & & 1.912663 \\
Prob(F-statistic) & 0.000145 & & \\
\hline
\end{tabular}

Nilai konstanta pada hasil pengujian ini dapat dilihat pada tabel 4.11. Dimana nilai konstanta yang diperoleh sebesar 28014,13 ini artinya jika variabel CCCit, CCCit-1, CCCit-2, CCCit-3 (X3), bernilai nol (0) maka nilai perusahaan akan mengalami peningkatan sebesar 28014,13. nilai koefisien regresi CCCit sebesar -155,67 ini menandakan bahwa setiap penambahan satu satuan CCCit akan menurunkan nilai perusahaan sebesar $-155,67$. Nilai koefisien regresi CCCit-1 sebesar -0,14 ini menandakan bahwa setiap penambahan satu satuan CCCit-1 akan menurunkan nilai perusahaan sebesar -0,14. Nilai koefisien regresi CCCit-2 sebesar -37,73 ini menandakan bahwa setiap penambahan satu satuan CCCit-2 akan menurunkan nilai perusahaan sebesar -37,73. Nilai koefisien regresi CCCit-3 sebesar 114,32 ini menandakan bahwa setiap penambahan satu satuan CCCit-3 akan meningkatkan nilai perusahaan sebesar 114,32. Nilai koefisien regresi CCCit-4 sebesar -125,69 ini menandakan bahwa setiap penambahan satu satuan CCCit-4 akan menurunkan nilai perusahaan sebesar -125,69.

Hasil regresi panel dengan menggunakan pendekatan random effect model untuk regresi persamaan ketiga.

Tabel 7

Hasil Estimasi Regresi Panel dengan Model Random Effect Persamaan 3

\begin{tabular}{ccccc}
\hline Variable & Coefficient & Std. Error & t-Statistic & Prob. \\
\hline C & 36570.56 & 5669.437 & 6.450474 & 0.0000 \\
OCCit & -225.1322 & 62.87650 & -3.580546 & 0.0004 \\
OCCit-1 & 14.84125 & 39.48788 & 0.375843 & 0.7074 \\
OCCit-2 & -26.97726 & 23.71352 & -1.137632 & 0.2567 \\
OCCit-3 & 76.34570 & 27.97563 & 2.729008 & 0.0069 \\
& & & \\
OCCit-4 & -39.63709 & 43.81829 & -0.904579 & 0.3668 \\
R-squared & 0.116858 & Mean dependent var & & 2698.478 \\
Adjusted R-squared & 0.094329 & S.D. dependent var & & 1.928600 \\
F-statistic & 5.186957 & Durbin-Watson stat & \\
Prob(F-statistic) & 0.000171 & & \\
\hline
\end{tabular}


Nilai konstanta pada hasil pengujian ini dapat dilihat pada tabel 4.12. Dimana nilai konstanta yang diperoleh sebesar 36570,56 ini artinya jika variabel OCCit, OCCit-1, OCCit-2, OCCit-3 (X4), bernilai nol (0) maka nilai perusahaan akan mengalami peningkatan sebesar 36570,56. nilai koefisien regresi OCCit sebesar $-225,13$ ini menandakan bahwa setiap penambahan satu satuan CCCit akan menurunkan nilai perusahaan sebesar -225,13. Nilai koefisien regresi OCCit-1 sebesar 14,84 ini menandakan bahwa setiap penambahan satu satuan OCCit-1 akan meningkatkan nilai perusahaan sebesar 14,84. Nilai koefisien regresi OCCit-2 sebesar -26,97 ini menandakan bahwa setiap penambahan satu satuan CCCit-2 akan menurunkan nilai perusahaan sebesar -26,97. Nilai koefisien regresi OCCit-3 sebesar 76,34 ini menandakan bahwa setiap penambahan satu satuan OCCit-3 akan meningkatkan nilai perusahaan sebesar 76,34. Nilai koefisien regresi OCCit-4 sebesar -39,63 ini menandakan bahwa setiap penambahan satu satuan OCCit-4 akan menurunkan nilai perusahaan sebesar -39,63.

\section{Uji Model}

Hasil estimasi persamaan pertama pada tabel 5 diatas, diketahui bahwa nilai adjusted $R^{2}$ yang diperoleh sebesar 0,126187 . Hal ini mengindikasikan bahwa kontribusi variabel independen terhadap variabel dependen sebesar $12,6 \%$ dan $87,4 \%$ ditentukan oleh variabel lain yang tidak dianalisis dalam model pada penelitian ini. Hasil estimasi persamaan kedua pada tabel 6 diatas, diketahui bahwa nilai adjusted $R^{2}$ yang diperoleh sebesar 0,096053. Hal ini mengindikasikan bahwa kontribusi variabel independen terhadap variabel dependen sebesar 9,6\% dan 90,4\% ditentukan oleh variabel lain yang tidak dianalisis dalam model pada penelitian ini. Hasil estimasi persamaan ketiga pada tabel 7 diatas, diketahui bahwa nilai adjusted $R^{2}$ yang diperoleh sebesar 0,094329. Hal ini mengindikasikan bahwa kontribusi variabel independen terhadap variabel dependen sebesar 9,4\% dan 90,6\% ditentukan oleh variabel lain yang tidak dianalisis dalam model pada penelitian ini.

Hasil pengolahan data persamaan pertama pada tabel 5 diatas menunjukkan $F_{\text {hitung yaitu }}$ sebesar 2,935085 dan nilai signifikan pada 0,000336 < 0,05. Sehingga ditarik kesimpulan bahwa persamaan regresi yang diperoleh dapat digunakan. Hasil pengolahan data persamaan kedua pada tabel 6 diatas menunjukkan $F_{\text {hitung }}$ yaitu sebesar 5,271643 dan nilai signifikan pada 0,000145 < 0,05 . Sehingga ditarik kesimpulan bahwa persamaan regresi yang diperoleh dapat digunakan. Hasil pengolahan data persamaan ketiga pada tabel 7 diatas menunjukkan $F_{\text {hitung }}$ yaitu sebesar 5,186957 dan nilai signifikan pada $0,000171<0,05$. Sehingga ditarik kesimpulan bahwa persamaan regresi yang diperoleh dapat digunakan.

Hipotesis Pertama dalam penelitian ini adalah jumlah hari dalam penjualan (DSO) berpengaruh negatif terhadap nilai perusahaan satu tahun kedepan. Dari tabel 5 diatas, dapat dilihat bahwa DSOit memiliki nilai koefisien bernilai negatif sebesar -0,6466 nilai t-statistik sebesar $-1,8136$ dan nilai probabilitas $-0,0713<0,10$ dan DSOit-2 memiliki nilai koefisien bernilai negatif sebesar $-107,1727$ nilai t-statistik sebesar $-2,3327$ serta nilai probabilitas $-0,0207$ $<0,05$. Artinya jumlah hari dalam penjualan (DSO) berpengaruh negatif signifikan terhadap nilai perusahaan satu tahun kedepan pada perusahaan manufaktur yang terdaftar di BEI periode 20172018. Dengan demikian hipotesis pertama $\left(\mathbf{H}_{1}\right)$ diterima.

Hipotesis kedua dalam penelitian ini adalah jumlah hari dalam persediaan (DIO) berpengaruh negatif terhadap nilai perusahaan satu tahun kedepan. Dari tabel 5 diatas, dapat dilihat bahwa DIOit memiliki nilai koefisien bernilai negatif sebesar -231,60 nilai t-statistik sebesar $-2,5474$ dan nilai probabilitas $-0,0117<0,05$. Artinya jumlah hari dalam persediaan (DIO) berpengaruh negatif signifikan terhadap nilai perusahaan satu tahun kedepan pada 
perusahaan manufaktur yang terdaftar di BEI periode 2017-2018. Dengan demikian hipotesis kedua $\left(\mathrm{H}_{2}\right)$ diterima.

Hipotesis ketiga dalam penelitian ini adalah cash conversion cycle (CCC) berpengaruh negatif terhadap nilai perusahaan satu tahun kedepan. Dari 6 diatas, dapat dilihat bahwa CCCit memiliki nilai koefisien bernilai negatif sebesar -155,67 nilai t-statistik sebesar -2,077 dan nilai probabilitas $-0,0391<0,05$ dan CCCit-4 memiliki nilai koefisien bernilai negatif sebesar -125,69 nilai t-statistik sebesar $-2,419$ serta nilai probabilitas $-0,0164<0,05$. Artinya cash conversion cycle (CCC) berpengaruh negatif signifikan terhadap nilai perusahaan satu tahun kedepan pada perusahaan manufaktur yang terdaftar di BEI periode 2017-2018. Dengan demikian hipotesis ketiga $\left(\mathrm{H}_{3}\right)$ diterima.

Hipotesis keempat dalam penelitian ini adalah operating cash cycle (OCC) berpengaruh negatif terhadap nilai perusahaan satu tahun kedepan. Dari tabel 7 diatas, dapat dilihat bahwa OCCit memiliki nilai koefisien bernilai negatif sebesar -225,13 nilai t-statistik sebesar -3,580 dan nilai probabilitas $-0,0004<0,05$. Artinya operating cash cycle (OCC) berpengaruh negatif signifikan terhadap nilai perusahaan satu tahun kedepan pada perusahaan manufaktur yang terdaftar di BEI periode 2017-2018. Dengan demikian hipotesis keempat (H4) diterima.

\section{PEMBAHASAN}

\section{Pengaruh Jumlah Hari dalam Penjualan (Days of Sales Outstanding) (DSO) terhadap Nilai Perusahaan}

Berdasarkan hasil analisis statistik pada perusahaan manufaktur ditemukan bahwa hipotesis $\mathrm{H}_{1}$ diterima, sehingga dapat disimpulkan bahwa DSO berpengaruh negatif terhadap nilai perusahaan satu tahun kedepan. Variabel Days of Sales Outstanding (X1) yaitu DSOit memiliki nilai koefisien regresi bernilai negatif sebesar -0,6466 nilai t-statistik sebesar -1,8136 dan nilai probabilitas $-0,0713<0,10$ serta DSOit-2 memiliki nilai koefisien bernilai negatif sebesar $-107,1727$ nilai t-statistik sebesar $-2,3327$ serta nilai probabilitas $-0,0207<0,05$. Artinya jumlah hari dalam penjualan (DSO) berpengaruh negatif signifikan terhadap nilai perusahaan satu tahun kedepan pada perusahaan manufaktur yang terdaftar di BEI periode 2017-2018. Kemampuan perusahaan untuk menerima pembayaran dari pelanggan atas barang yang telah dikirim atau jasa yang telah diberikan secara tepat waktu dapat meningkatkan likuiditas perusahaan (Gallinger, 1997 dalam Kroes dan Manikas, 2014). Berdasarkan pengujian hipotesis ini dapat diartikan bahwa penurunan jumlah hari dalam penjualan atau penurunan jumlah hari untuk menagih piutang dapat meningkatkan likuiditas perusahaan, sehingga nilai perusahan meningkat signifikan.

Kas yang diterima dari pelanggan dapat digunakan untuk berinvestasi dalam aktivitas yang bertujuan untuk promosi penjualan tambahan. Oleh karena itu semakin cepat pembayaran diterima (semakin singkat DSO perusahaan) semakin besar peluang perusahaan untuk melakukan kegiatan tersebut. Meskipun mempersingkat DSO dapat terlihat tidak menguntungkan bagi pelanggan, perusahaan sering memanfaatkan insentif, seperti potongan pembayaran dalam upaya untuk mempersingkat siklus DSO perusahaan tanpa merusak hubungan dengan pelanggan (Moran, 2011). Hal ini sesuai dengan teori manajemen modal kerja yang menyatakan bahwa DSO yang lebih singkat dapat meningkatkan kinerja keuangan perusahaan yang pada akhirnya dapat meningkatkan nilai perusahaan. Temuan ini dapat memberikan wawasan tambahan tentang pentingnya manajemen aliran kas bagi perusahaan manufaktur. Temuan ini memberikan bukti yang kuat bahwa ketika suatu perusahaan mempersingkat DSO nya melalui hubungan yang lebih 
baik dengan pelanggan dan metode lainnya dan perusahaan dapat mempertahankan peningkatan kinerja keuangan ini hingga satu tahun.

Mengurangi DSO dapat meningkatkan likuiditas perusahaan, yang memungkinkan perusahaan untuk berinvestasi dalam peluang pertumbuhan bisnis baru. Implementasi dan manfaatnya mungkin memerlukan waktu beberapa kuartal kedepan agar bisa terwujud. Penurunan dalam DSO sering kali melibatkan peningkatakan hubungan pelanggan dan komunikasi, merupakan peningkatan jangka panjang yang berkelanjutan bagi kedua belah pihak yang kemungkinan akan berlanjut untuk periode waktu yang lama.

\section{Pengaruh Jumlah Hari dalam Persediaan (Days of Inventory Outstanding) (DIO) terhadap Nilai Perusahaan}

Berdasarkan hasil analisis statistik pada perusahaan manufaktur ditemukan bahwa hipotesis $\mathrm{H}_{2}$ diterima, sehingga dapat disimpulkan bahwa DIO berpengaruh negatif terhadap nilai perusahaan satu tahun kedepan. Variabel Days of Inventory Outstanding (X2) yaitu DIOit memiliki nilai koefisien bernilai negatif sebesar -231,6019 nilai t-statistik sebesar -2,5474 dan nilai probabilitas $-0,0117<0,05$. Artinya jumlah hari dalam persediaan (DIO) berpengaruh negatif signifikan terhadap nilai perusahaan satu tahun kedepan pada perusahaan manufaktur yang terdaftar di BEI periode 2017-2018. Berdasarkan pengujian hipotesis ini dapat diartikan bahwa penurunan jumlah hari dalam persediaan atau penurunan jumlah hari untuk menjual persediaan dapat meningkatkan likuiditas perusahaan, sehingga nilai perusahan meningkat signifikan.

Tingkat persediaan yang berlebihan mengakibatkan operasional dan kinerja keuangan menjadi buruk (Singhal, 2005). Perusahaan biasanya harus menyediakan barang untuk pelanggan mereka secara tepat waktu, artinya kekurangan dalam persediaan dapat menyebabkan penurunan pelayanan pada pelanggan dan volume penjualan akan turun dibawah tingkat yang dapat dicapai. Namun dengan mengadakan persediaan, akan mengakibatkan kas tidak tersedia dalam perusahaan karena diinvestasikan dalam persediaan dan perusahaan terpaksa untuk mengeluarkan biaya penyimpanan, asuransi, pajak, keusangan dan kerusakan fisik. Oleh karena itu penurunan persediaan dapat mengurangi biaya tersebut dan mengembalikan kas yang dapat diinvestasikan kembali untuk meningkatkan penjualan (Kroes dan Manikas, 2014).

Periode penyimpanan persediaan yang lebih singkat (DIO yang lebih rendah) berhubungan dengan peningkatan likuiditas dan kinerja keuangan perusahaan yang lebih baik (Koumanakos, 2009), karena penurunan persediaan dapat mengurangi biaya penyimpanan, asuransi, pajak, keusangan dan kerusakan fisik dan mengembalikan kas yang dapat diinvestasikan kembali untuk meningkatkan penjualan. Sesuai dengan konsep manajemen modal kerja, dimana perusahaan dengan penerapan modal kerja yang baik akan memiliki tingkat likuiditas dan profitabilitas yang tinggi (Setyanto dan Permatasari, 2014). Perusahaan dengan pofitabilitas yang baik memiliki kesempatan untuk bertumbuh secara konsisten, dimana pertumbuhan tersebut pada akhirnya akan meningkatkan nilai perusahaan (Varaiya et al., 1987).

\section{Pengaruh Siklus Konversi Kas (Cash Conversion Cyce) (CCC) terhadap Nilai Perusahaan}

Berdasarkan hasil analisis statistik pada perusahaan manufaktur ditemukan bahwa hipotesis $\mathrm{H}_{3}$ diterima, sehingga dapat disimpulkan bahwa CCC berpengaruh negatif terhadap nilai perusahaan satu tahun kedepan. Variabel Cash Conversion Cycle (X3) yaitu CCCit memiliki nilai koefisien bernilai negatif sebesar -155,67 nilai t-statistik sebesar -2,077 dan nilai probabilitas $-0,0391<0,05$ serta CCCit-4 memiliki nilai koefisien bernilai negatif sebesar - 
125,69 nilai t-statistik sebesar $-2,419$ serta nilai probabilitas $-0,0164<0,05$. Artinya cash conversion cycle (CCC) berpengaruh negatif signifikan terhadap nilai perusahaan satu tahun kedepan pada perusahaan manufaktur yang terdaftar di BEI periode 2017-2018. Cash Conversion Cycle (CCC) yang lebih singkat secara teoritis berhubungan dengan peningkatan likuiditas perusahaan dan peningkatan kinerja keuangan perusahaan (Garcia dan Martinez, 2007). Siklus konversi kas yang pendek menunjukkan bahwa perusahaan mengelola dan memproses inventaris lebih cepat dan memperlambat pembayaran kas kepada pemasok. Hal ini dapat meningkatkan efisiensi operasional internal, menghasilkan profitabilitas yang tinggi, meningkatkan nilai sekarang dari arus kas dan meningkatkan nilai pasar suatu perusahaan (Nobanee dan Abdullatif, 2010). Sesuai dengan konsep manajemen modal kerja, dimana perusahaan dengan penerapan modal kerja yang baik akan memiliki tingkat likuiditas dan profitabilitas yang tinggi.

Berdasarkan pengujian hipotesis ini dapat diartikan bahwa penurunan siklus konversi kas (CCC) dapat meningkatkan profitabilitas perusahaan, sehingga nilai perusahan meningkat signifikan. Peningkatan profitabilitas perusahaan melalui siklus konvesi kas yang singkat dapat terjadi karena perusahaan mampu mengumpulkan kas yang diperlukan untuk kegiatan operasional dengan lebih cepat. Pada saat profitabilitas perusahaan mengalami peningkatan, tidak menutup kemungkinan bahwa jumlah deviden yang diterima oleh para pemegang saham juga akan mengalami peningkatan. Adanya peningkatan dalam jumlah deviden mengindikasikan bahwa tingkat kesejahteraan pemegang saham perusahaan semakin tinggi dan pada akhirnya perusahaan yang bersangkutan akan memiliki nilai yang tinggi dimata investor (Setyanto dan Permatasari, 2014).

Suatu bisnis akan berupaya untuk melanjutkan dan meningkatkan kinerja keuangan mereka, oleh karena itu penting bagi mereka untuk memantau dengan cermat siklus konversi kas perusahaannya. Manajemen kas didasarkan kepada cash conversion cycle dan dianggap sebagai faktor penting yang dapat meningkatkan kinerja dan nilai perusahaan, karena menunjukkan seberapa efisien suatu perusahaan dalam menjual persediaan, membayar tagihan dan menagih pembayaran dalam kegiatan operasi. Siklus konversi kas yang singkat dapat dilakukan dengan mengurangi periode penagihan piutang, mengurangi periode penjualan persediaan dan menambah atau memperpanjang periode pembayaran kredit (Linh dan Mohanllingam, 2018).

\section{Pengaruh Operating Cash Cyce (OCC) terhadap Nilai Perusahaan}

Berdasarkan hasil analisis statistik pada perusahaan manufaktur ditemukan bahwa hipotesis $\mathrm{H}_{4}$ diterima, sehingga dapat disimpulkan bahwa OCC berpengaruh negatif terhadap nilai perusahaan satu tahun kedepan. Variabel operating cash cycle (X4) yaitu OCCit memiliki nilai koefisien bernilai negatif sebesar $-225,13$ nilai t-statistik sebesar $-3,580$ dan nilai probabilitas $-0,0004<0,05$. Artinya operating cash cycle (OCC) berpengaruh negatif signifikan terhadap nilai perusahaan satu tahun kedepan pada perusahaan manufaktur yang terdaftar di BEI periode 2017-2018. Berdasarkan pengujian hipotesis ini dapat diartikan bahwa penurunan operating cash cycle (OCC) dapat meningkatkan likuiditas dan kinerja keuangan perusahaan, sehingga nilai perusahan meningkat signifikan. Operating cash cycle (OCC) yang lebih singkat berhubungan dengan likuiditas dan kinerja perusahaan yang lebih baik (Churchill dan Mullins, 2001). Operating cash cycle yang lebih pendek menunjukkan bahwa kas perusahaan terikat untuk jangka waktu yang lebih pendek yang umumnya lebih ideal dari perspektif arus kas (Churchill dan Mullins, 2001). 
Jika perusahaan diberi lebih banyak waktu untuk membayar pemasoknya, perusahaan dapat mengurangi operating cash cycle dengan menunda pengeluaran kas. Sebaliknya, jika perusahaan memberi pelanggan lebih banyak waktu untuk membayar piutang, hal ini dapat memperpanjang operating cash cycle karena perusahaan harus menunggu lebih lama untuk mendapatkan kas. Melalui kebijakan manajemen modal kerja yang efisien berarti perusahaan menerapkan siklus kas operasi yang singkat. Siklus kas operasi yang singkat mengindikasikan bahwa kas yang terikat dalam modal kerja lebih sedikit, sehingga tersedianya kas yang diperlukan untuk kegiatan operasional perusahaan. Oleh karena itu perusahaan tidak perlu memakai maupun mencari tambahan sumber pendanaan yang berasal dari luar perusahaan. Ketika perusahaan tidak membutuhkan pendanaan tambahan dari pihak lain maka hal itu berarti tidak ada tambahan biaya yang harus dikeluarkan untuk pinjaman dana, sehingga selanjutnya keuntungan perusahaan akan dapat meningkat yang pada akhirnya dapat meningkatkan nilai perusahaan.

\section{SIMPULAN, KETERBATASAN DAN SARAN \\ Simpulan}

Berdasarkan hasil temuan penelitian dan pengujian hipotesis yang telah dilaksanakan, hasil penelitian didapatkan bahwa:

1. Days of sales outstanding (DSO) pada perusahaan manufaktur berpengaruh negatif terhadap nilai perusahaan satu tahun kedepan.

2. Days of invetory outstanding (DIO) pada perusahaan manufaktur berpengaruh negatif terhadap nilai perusahaan satu tahun kedepan.

3. Cash conversion cycle (CCC) pada perusahaan manufaktur berpengaruh negatif terhadap nilai perusahaan satu tahun kedepan.

4. Operating Cash Cyle (OCC) pada perusahaan manufaktur berpengaruh negatif terhadap nilai perusahaan satu tahun kedepan.

\section{Keterbatasan}

Peneliti telah berusaha merancang dan mengembangkan penelitian ini secara maksimal, namun masih ada kelemahan dalam penelitian yaitu :

1. Karena menggunakan data triwulanan maka laporan keuangan yang digunakan tidak diaudit sehingga tingkat kualitas kewajaran laporan keuangan belum dapat dijelaskan.

2. Periode penelitian ini hanya mencakup 2 tahun dengan sampel 101 dari 175 populasi. Hal ini dikarenakan keterbatasan informasi terkait variabel penelitian yang tidak lengkap.

3. Penelitian ini hanya menggunakan satu jenis industri perusahaan saja sehingga belum mampu mewakili seluruh perusahaan yang terdaftar di BEI.

\section{Saran}

Seusai dengan kesimpulan dari hasil penelitian yang telah dijelaskan diatas dapat diberikan saran yaitu:

1. Penelitian selanjutnya dapat menggunakan objek lain, tidak hanya pada perusahaan manufaktur yang terdaftar di BEI, tetapi juga industri dari sektor lainnya atau berasal dari semua jenis perusahaan publik.

2. Penelitian selanjutnya juga dapat menggunakan proksi lain sebagai alat ukur nilai perusahaan, seperti proksi PBV. 
3. Penelitian selanjutnya juga dapat memperpanjang periode penelitian dan tolak ukur sehingga diketahui pengaruhnya secara lebih rinci.

4. Penelitian-penelitian selanjutnya agar dapat menggunakan keputusan investasi, keputusan pendanaan, profitabilitas, growth opportunity sebagai variabel independen yang bisa memperlihatkan hal-hal yang lebih mempengaruhi nilai perusahaan selain variabel yang telah diteliti.

\section{DAFTAR PUSTAKA}

Achabal, D. D., Mcyntyre, S. H., Smith, S. A., \& Kalyanam, K. (2000). A Decision Support System for Vendor Managed Inventory. Journal of Retailing, 76 (4) , 430-454.

Azhar, N. E., \& Noriza. (2010). Working Capital Management: The Effect of Market Valuation and Profitability in Malaysia. International Journal of Business and Management, 5 (11), 140-147.

Azhari, H. (2013). Pengaruh Kebijakan Hutang dan Kebijakan Deviden tehadap Nilai Perusahaan. Disertasi (Tidak Dipublikasikan). Program Studi Akuntansi Fakultas Ekonomi Universitas Negeri Padang.

BDBC. (2014). Cash Flow Management BDC Viewpoints Study. Business Development Bank of Canada, 1-14.

Brigham, E. F., \& Houston, J. F. (2001). Manajemen Keuangan Edisi 8 . Jakarta: Erlangga.

Capkun, V., Hameri, A. P., \& Weiss, L. A. (2009). On the Relationship Between Inventory and Financial Performance in Manufacturing Companies. International Journal of Operations \& Production Management, 29 (8) , 789-806.

Ching, H. Y., Novazzi, A., \& Gerab, F. (2011). Relationship Between Working Capital Management and Profitability In Brazilian Listed Companies . Journal of Global Business and Economics, 3 (1) , 74-86.

Churchill, N. C., \& Mullins, J. W. (2001). How Fast Can Your Company Afford to Grow? Harvard Business Review.

Deloof, M. (2003). Does Working Capital Management. Journal of Business Finance \& Accounting, 30(3) \& (4), 573-587.

Dipanala, S. (2018). Analisis Faktor-Faktor yang Mempengaruhi Nilai Perusahaan dengan Kepemilikan Manajerial Sebagai Variabel Kontrol. Disertasi (Dipublikasikan). Universitas Diponegoro, 1-31.

Ebben, J. J., \& Johnson, A. C. (2011). Cash Conversion Cycle Management in Small Firms Relationships with Liquidity, Invested Capital, and Firm Performance. Journal of Small Business \& Entrepreneurship, 24 (3), 381-396.

Farris, M. T., \& Hutchison, P. D. (2002). Cash-to-Cash : The New Supply Chain Management Metric. International Journal of Physical Distribution \& Logistics Management , 288298.

Fisher, L. M. (1998, January 1). Inside Dell Computer Corporation : Managing Working Capital. Dipetik September 2, 2019, dari Strategy+Business: https://www.strategybusiness.com/article/9571?gko $=\mathrm{d} 8 \mathrm{c} 29$

Frees, E. W. (2004). Longitudinal and Panel Data Analysis and Applications in the Social Sciences. United States of America: Cambridge University Press.

García-Teruel, P. J., \& Martínez-Solano, P. M.-S. (2007). Effects of working capital management on. International Journal of Managerial Finance, 3 (2) , 164-177. 
Gill, A., Biger, N., \& Mathur, N. (Volume 2010 : BEJ-10). The Relationship Between Working Capital Management And Profitability: Evidance From The United States. Business and Economics Journal , 1-9.

Harford, J., Mansi, S. A., \& Maxwell, W. F. (2008). Corporate governance and firm cash holdings in the US. Journal of Financial Economics, 535-555.

Hsiao, C. (2007). Panel data analysis - advantages and challenges. 1-22.

Jusriani, I. F. (2013). Analisis Pengaruh Profitabitas, Kebijakan Dividen, Kebijakan Utang dan Kepemilikan Manajerial Terhadap Nilai Perusahaan. Skripsi Universitas Diponegoro yang dipublikasikan , 1-77.

Kallapur, S., \& Trombley, M. A. (1999). The Association Between Investment Opportunity Set Proxies and Realized Growth. Journal of Business Finance \& Accounting, 26(3) \& (4), 505-519.

Kasmir. (2010). Pengantar Manajemen Keuangan. Jakarta : Kencana.

Keown, A. J., Martin, J. D., Petty, J. W., \& Scott, D. F. (2010). Manajemen Keuangan.

Koumanakos, D. P. (2008). The Effect of Inventory Management on Firm Performance. International Journal of Productivity and Performance Management, 57 (5) , 355-369.

Kroes, J. R., \& Manikas, A. S. (2014). Cash Flow Management and Manufacturing Firm Financial Performance : A Longitudinal Perspective. Int. j. Production Economics , 3750.

Linh, N. T., \& Mohanlingam, S. (2018). The Effects of Cash Conversion Cycle on. Asian Journal of Business and Accounting, 11(1), 97-119.

Martha, I. C., \& Januarti, I. (2013). Pengaruh Siklus Konversi Kas terhadap Profitabilitas Perusahaan Manufaktur di Bursa Efek Indonesia tahun 2008-2011. Diponegoro Journal of Accounting , 1-11.

Milgrom, P., \& Roberts, J. (1998). Communication and Inventory as Substitutes in Organizing Production. Journal of Economics 90 (3) , 275-289.

Muraya, A. M. (2018). Effect of Cash Flow on Financial Performance of Investment Firms Listed in the Nairobi Securities Exchange. Thesis United States International Univesity Africa , 1-112.

Myres, M. B., Daugherty, P. J., \& Autry, C. W. (2000). The Effectiveness of Automatic Inventory Replenishment in Supply Chain Operations: Antecedents and Outcomes. Journal of Retailing, Volume 76(4) , 455-481.

Nerlove, M. (2002). Essays in Panel Data Econometric. 1-12.

Nobanee, H., Abdullatif, M., \& AlHajjar, M. (2010). Cash Conversion Cycle and Firm's Performance of Japanese Firms. 1-12.

Ozbayrak, M., \& Akgun, M. (2006). The effects of manufacturing control strategies on the cash conversion cycle in manufacturing systems. Int. J. Production Economics, 535-550.

Puspitasari, R. (2010). The Analysis of Operational Cash Flow in Achieving Company's Optimal Value. Jurnal Ilmiah Kesatuan Nomor 2 Volume 12 , 1-7.

Quinn, M. (2011, Oktober 5). Forget About Profit, Cash Flow Is King. Dipetik September 1, 2019, dari The Wall Street Journal : http://refhub.elsevier.com/S0925-5273(13)004672/sbref48

Raharjaputra, H. S. (2009). Manajemen Keuangan dan Akuntansi . Jakarta: Salemba Empat.

Raheman, A., \& Nasr, M. (2007). Working Capital Management And Profitability - Case Of Pakistani Firms. International Review of Business Research Papers, 3 (1) , 279-300. 
Richards, V. D., \& Laughlin, E. J. (1980). A Cash Conversion Cycle Approach to Liquidity Analysis. Financial Management, 9 (1), 32-38.

Setyanto, A. D., \& Permatasari, I. (2014). Manajemen Modal Kerja dan Dampaknya terhadap Nilai Perusahaan dengan Corporate Governance sebagai Variabel Pemoderasi. Jurnal Akuntansi Akrual, 6 (1), 66-82.

Shah, R., \& Shin, H. (2007). Relationships among information technology, inventory and profitability: An investigation of level invariance using sector level data. Journal of Operations Management, 768-784.

Singhal, V. R. (2005). Excess Inventory and Long-Term Stock Price Performance. Working Paper, 1-36.

Stewart, G. (1995). "Supply chain performance benchmarking study reveals keys to supply chain excellence", Logistics Information Management. Logistics Information Management, 8 (2) , 38-44.

Subramanyam. (2010). Analisis Laporan Keuangan. Salemba Empat.

Sugathadasa, D. (2018). The Relationship between Cash Conversion Cycle and Firm Profitability: Special Reference to Manufacturing Companies in Colombo Stock Exchange. IOSR Journal of Economics and Finance (IOSR-JEF) Volume 9, Issue 6 Ver. II , 38-47.

Sujoko, \& Soebiantoro, U. (2007). Pengaruh Struktur Kepemilikan Saham, Leverage, Faktor Intern Dan FaktorEkstern Terhadap Nilai Perusahaan. Jurnal Manajemen Dan Kewirausahaan, 9 (1) , 41-48.

Swaminathan, J. M., Smith, S. F., \& Sadeh, N. M. (1998). Modeling Supply Chain Dynamics: A Multiagent Approach. Decision Sciences Volume, 29 (3) , 607-632. 